\title{
Antiplatelet treatment in the primary prophylaxis of cardiovascular disease in patients with arterial hypertension
}

\author{
Angelika Osińska ${ }^{1}$, Maciej Osiński $^{2}$, Aleksandra Krasińska ${ }^{3}$, Beata Begier-Krasińska ${ }^{1}$ \\ ${ }^{1}$ Department of Hypertensiology, Angiology, and Internal Diseases, Poznan University of Medical Sciences, Poznań, Poland \\ 2Department of Obstetrics, Gynecology, and Gynecological Oncology, Division of Reproduction, Poznań University of Medical \\ Sciences, Poznań, Poland \\ ${ }^{3}$ Medical Faculty, Poznan University of Medical Sciences, Poznań, Poland
}

Kardiochirurgia i Torakochirurgia Polska 2017; 14 (2): 133-136

\begin{abstract}
The benefits of using acetylsalicylic acid (ASA) in the primary prophylaxis of cardiovascular diseases may only slightly exceed the risk of serious bleeding. This warrants the search for alternative, safer preparations with antiaggregatory properties, which could be used in patients burdened with cardiovascular risk factors. Antiaggregatory compounds identified in water-soluble tomato extract include nucleosides, flavonoids, and phenolic acids. The action of standardized tomato extract is multidirectional, reversible, and weaker in comparison to ASA. The European Food Safety Authority (EFSA) has approved this preparation as a dietary agent with antiaggregatory properties. The use of standardized tomato extract appears beneficial in arterial hypertension patients with low or moderate cardiovascular risk and in patients in whom good pressure control cannot be achieved.
\end{abstract}

Key words: acetylsalicylic acid, standardized tomato extract.

\section{Streszczenie}

Korzyści ze stosowania kwasu acetylosalicylowego (ASA) w profilaktyce pierwotnej chorób sercowo-naczyniowych mogą w niewielkim stopniu przewyższać ryzyko poważnych krwawień Dlatego zasadne jest poszukiwanie alternatywnych do ASA bezpiecznych preparatów o właściwościach antyagregacyjnych, które będą mogły być stosowane u osób, u których występują czynniki ryzyka chorób sercowo-naczyniowych. Do związków o właściwościach antyagregacyjnych, które zostały zidentyfikowane $\mathrm{w}$ rozpuszczalnym w wodzie ekstrakcie z pomidora, należą: nukleozydy, flawonoidy i kwasy fenolowe. Działanie standaryzowanego ekstraktu z pomidorów jest wielokierunkowe, odwracalne i słabsze w porównaniu z ASA. Europejska Agencja ds. Bezpieczeństwa Żywności zaakceptowała ten preparat jako środek dietetyczny o właściwościach antyagregacyjnych. Wydaje się, że zastosowanie standaryzowanego ekstraktu z pomidorów u pacjentów chorujących na nadciśnienie tętnicze z grup niskiego i umiarkowanego ryzyka sercowo-naczyniowego oraz u pacjentów nieosiągających dobrej kontroli ciśnienia jest korzystne.

Słowa kluczowe: kwas acetylosalicylowy, standaryzowany ekstrakt z pomidorów.

vessels. Considering the fact that blood platelets have no cellular nuclei, preventing them from synthesizing cyclooxygenase, the antiaggregatory action of ASA is irreversible; in other words, it persists until a new generation of platelets is produced. This determines the duration of aspirin's antiaggregatory action, which lasts for approx. 10 days [2]. The most common adverse effects of ASA are: heartburn, gastric ailments, and microischemias of the gastric mucosa resulting from the inhibition of prostaglandin E2 (PGE2) production. Chronic ASA use is associated with rare or very rare occurrence of severe adverse effects that can be life-threatening. These consist in serious bleeding,

Address for correspondence: Angelika Osińska MD, Department of Hypertensiology, Angiology, and Internal Diseases, Poznan University of Medical Sciences, 1/2 Długa St, 61-848 Poznań, Poland, phone: +48 61854 90 90, fax: +48 6185490 86, e-mail: angelika.miazga@gmail.com Received: 22.05.2017, accepted: 13.06.2017. 
such as gastrointestinal tract bleeding or cerebral bleeding (especially in patients with uncontrolled hypertension and/or receiving antithrombotic agents) [3]. Some patients develop high on-treatment platelet reactivity (HTPR), i.e., re-sistance to antiplatelet treatment. Aspirin resistance is a common clinical problem; various clinical studies estimate its prevalence at $2-57 \%$ [4]. The results obtained by a study using the VerifyNow Aspirin test appear credible; the authors analyzed 468 patients with stable ischemic heart disease and revealed aspirin resistance in $27.4 \%$ of the analyzed subjects. The causes of weak response to ASA include: obesity [5], reduced absorption [6], drug interactions [7], hyperglycemia, hypercholesterolemia, oxidative stress [8], or increased catecholamine concentrations [9]. The etiology of resistance to acetylsalicylic acid is multifactorial. Weber et al. put forward a pharmacological classification of abnormal response to ASA, distinguishing its three subtypes: pharmacokinetic resistance, pharmacodynamic resistance, and pseudo-resistance to aspirin. The researchers demonstrated that one of the most common reasons for the apparent lack of ASA's efficacy is patient non-compliance: skipping doses or lack of aspirin use [10]. According to some reports, approx. $40 \%$ of cardiovascular patients use ASA irregularly [11, 12]. Numerous studies list factors that increase blood platelet activity and can be responsible for reduced response to ASA, including: diabetes, obesity, nicotinism, arterial hypertension, hypercholesterolemia, heart failure, acute coronary syndrome, as well as postoperative status after coronary angioplasty or coronary artery bypass grafting [13]. The use of acetylsalicylic acid in secondary prophylaxis reduces the risk of serious cardiovascular events. Recommending ASA in the primary prophylaxis of cardiovascular disease (CVD) always requires one to estimate the trade-off between the benefits of its antiaggregatory properties and the risk of bleeding; the issue continues to be a matter of debate among experts. There is a tendency not to recommend ASA for primary prophylaxis, which stems from meta-analysis results indicating that ASA use is associated with increasing the risk of serious bleeding [14]. According to the current guidelines of the Polish Society of Hypertension, acetylsalicylic acid dosed at $75 \mathrm{mg}$ can be administered to patients with arterial hypertension and high (20-30\%) or very high (>30\%) global cardio-vascular risk (assessed with the Framingham Risk Score). In turn, ASA administration is not recommended when the risk is low or intermediate. Therapy should be started after the normalization of arterial pressure values in order to minimize possible adverse effects. According to the European Society of Cardiology (ESC) guidelines on CVD prevention in clinical practice from 2016, ASA should not be used in patients who are not diagnosed with CVD due to the increased risk of serious bleeding. The Antithrombotic Trialists' Collaboration published data from 6 studies encompassing 95,000 subjects; the authors investigated the role of prevention in individuals without cardiovascular or cerebrovascular disease, comparing patients receiving ASA with a control group. The results indicated a $12 \%$ reduction in the risk of serious cardiovascular events $(0.51 \%$ aspirin group vs. $0.57 \%$ control group; $p=0.0001$ ) and a $20 \%$ reduction in infarction risk per year. The incidence of serious (fatal or requiring blood transfusion) gastrointestinal and extracranial hemorrhages increased by $0.03 \%$ per year. The risk of vascular mortality was unaffected by the use of ASA [15]. The year 2011 saw the publication of a metaanalysis of 9 randomized prospective clinical studies encompassing over 100,000 patients without atherosclerotic symptoms. The publication evaluated the influence of acetylsalicylic acid vs. placebo on the occurrence of fatal and non-fatal cardiovascular events as well as serious hemorrhages. In the ASA group, the cardiovascular incident risk increased by $10 \%$, while the risk of major bleeding rose by $62 \%$ in comparison to the control group. For every 1,000 patients treated with ASA over the period of 5 years, aspirin prevented 3 cardiovascular events and caused 3 major hemorrhages. The results were deemed insufficient to recommend the use of ASA for primary CVD prevention in patients without clinical evidence for atherosclerosis [16]. The American College of Chest Physicians recommends the use of ASA prophylaxis (75-100 mg) in individuals over 50 years of age with high stratified risk of CVD occurrence, even if they have no symptomatic cardiovascular disease [17]. The American Diabetes Association (ADA), American College of Cardiology (ACC), and American Heart Association (AHA) recommend the use of ASA for primary prophylaxis in diabetics with >10\% risk of cardiovascular episodes, but without an increased risk of gastrointestinal bleeding. This patient group includes: women $>60$ years and men $>50$ years with 1 or more risk factors (dyslipidemia, arterial hypertension, nicotinism, microalbuminuria, or family history of premature CVD) [18].

\section{Standardized tomato extract in the primary prophylaxis of ischemic heart disease}

The importance of diet (low in animal fats, rich in fruits and vegetables) is underscored in the prophylaxis of cardiovascular disease. According to the report by the World Health Organization (WHO) from 2002, low consumption of fruits and vegetables is responsible for $31 \%$ of cases of ischemic heart disease and $11 \%$ of strokes around the world [19].

Tomatoes are a particularly valuable dietary component; their properties are well-established, and they play an significant role in preventing cardiovascular disease. They are an important source of vitamins, mineral components, an biologically active compounds with antiaggregatory and anti-inflammatory properties, reducing arterial pressure and offering health benefits. Tomatoes are rich in potassium, an element indispensable for regulating cardiac rhythm and controlling arterial pressure, as well as the antioxidant vitamins C and E [20]. Standardized tomato extract (STE) is a water-soluble tomato concentrate without lycopene or fats, containing 37 biologically active compounds of established structure. These compounds include nucleosides (adenosine, cytidine, guanosine, inosine, AMP, GMP), poly- 
phenols (including flavonoids: rutin, quercetin, kaempferol, luteolin, naringenin), and phenolic acids (chlorogenic, caffeic, p-coumaric, ferulic) [21, 22]. Standardized tomato extract is approved for trade in two forms: syrup and powder. In 2009, the European Food Safety Authority (EFSA) approved water-soluble tomato concentrate (WSTC) as a dietary agent helpful in maintaining proper aggregation of blood platelets. EFSA recommends the use of STE in healthy individuals between the ages of 35 and 70 . The effective daily dose was established at $3 \mathrm{~g}$ of bioactive compounds in syrup or 65-150 mg in powder [23, 24]. The document was based on the results of 8 human and 7 animal studies [23]. Dutta-Roy et al. published a study 2001, which investigated antiplatelet properties of various fruits and vegetables in vitro. Among all the studied substances, tomato products exhibited the highest antiaggregatory activity, followed by grapefruit, melon, and strawberry products. Tomato extract inhibited ADP- and collagen-induced aggregation by as much as $70 \%$ without inhibiting blood platelet aggregation induced by arachidonic acid and the accompanying synthesis of thromboxane. O'Kennedy et al. studied healthy individuals, demonstrating that factors contained in watersoluble tomato extract exhibited antiplatelet activity both in vitro and in vivo. In a randomized double-blinded crossover study conducted among 90 healthy individuals aged 45-70, the authors evaluated the impact of tomato extract on platelet aggregation. The amount of bioactive substances contained in the extracts that were added to beverages received by the patients was equivalent to that contained in 2-6 fresh tomatoes. Tomato extract equivalent to 6 tomatoes caused a $17.5 \%$ reduction in collagen-induced platelet aggregation as well as a $7.8 \%$ and $21.3 \%$ reduction in ADP-induced aggregation (at 7.5 and $3 \mu \mathrm{mol}$ ADP/l, respectively). The effect of aggregation inhibition was observed in $97 \%$ of participants. Another study, conducted among 47 healthy individuals, demonstrated similar effects of a single dose of STE and $75 \mathrm{mg}$ of acetylsalicylic acid in terms of antiplatelet action (PFA-100 closure time) and influence on thromboxane A2 synthesis. When ASA was administered over 7 days, the PFA-100 closure time was three times longer than in the case of a single aspirin dose, which indicates that the effect of platelet aggregation inhibition exerted by acetylsalicylic acid is three times stronger than that of STE in chronic therapy.

Standardized tomato extract inhibits platelet aggregation in response to ADP, collagen, arachidonic acid, and thrombin in vitro [24]. The mechanism of STE action is multidirectional. Among other things, studies demonstrated that polyphenols influence the inhibition of fibrin aggregation, secretion, and binding by blocking protein disulfide isomerase (PDI). Tomato extract blocks receptors for ADP, collagen, and von Willebrand factor; it prevents the activation of the $\alpha$ llb $\beta 3$ integrin, inhibits the activation of the GPIIb/IIla glycoprotein, and inhibits the expression of Pselectin on the platelet surface. Standardized tomato extract also increases the concentration of CAMP and cGMP in platelet cytosol. Standardized tomato extract components are likely responsible for inactivating tissue factor (TF), a protein activating the extrinsic pathway of the coagulation cascade $[25,26]$. In vitro animal and human studies demonstrated that tomato extract inhibits the activation of inflammatory processes in the endothelium, countering the development of atherosclerosis. Standardized tomato extract was shown to reduce the production of inflammatory cytokines (TNF- $\alpha, \mathrm{IL}-1 \beta, \mathrm{IL}-12$ ) and increase the synthesis of the anti-inflammatory interleukin 10 [27]. Moreover, phenolic acids contained in tomato extract were shown to inhibit the expression of the nuclear factor $\kappa B(N F-\kappa B)$ transcription factor, which participates in inflammatory response in the course of atherosclerosis [28]. It has also been demonstrated that STE reduces the expression of cell adhesion molecules (ICAM-1, VCAM-1) in endothelial cells, which play an important role in the formation of atherosclerotic plaque [27]. Furthermore, there are reports describing the role of hypotensive properties of STE polyphenols in the mechanism of angiotensin-converting enzyme (ACE) inhibition [29]. In 2015, the guidelines of the Polish Society of Hypertension for the first time allowed the use of other substances (including STE) as alternatives to ASA. In view of these recommendations, the use of antiaggregatory preparations whose effects were confirmed by clinical studies (e.g., STE) can be considered for primary prophylaxis in patients with uncomplicated arterial hypertension and moderate or high cardiovascular risk [15].

It is noteworthy that, while STE action is reversible, ASA action is not. In this context, the former preparation appears to be a safer option for primary antiaggregatory prevention.

In conclusion, arterial hypertension constitutes an important risk factor for cardiovascular diseases, which are the most common cause of death worldwide. In patients with conditions from this group, primary prophylaxis is aimed at combating and modifying cardiovascular risk factors by promoting healthier lifestyles and introducing preventive pharmacotherapy. Statins and acetylsalicylic acid have been proven effective in this regard. The latter can relatively often lead to serious bleeding, including central nervous system or gastrointestinal bleeding. Therefore, ASA is recommended for all patients after CVD episodes (as secondary prophylaxis), but its use for primary prophylaxis continues to be debated. The risk of adverse effects associated with the use of acetylsalicylic acid warrants the search for alternative, safer substances with antiplatelet action, but with no adverse effects. Standardized tomato extract with its reversible (and thus safer) antiplatelet action may be one such substance. The results presented above demonstrate the efficacy of STE in inhibiting platelet aggregation in hypertensive patients. This may suggest that arterial hypertension patients without previous CVD episodes can benefit from the use of STE in primary prophylaxis.

\section{Disclosure}

Authors report no conflict of interest. 


\section{References}

1. Kubica J, Koziński M, Grześk G. Mechanizmy działania leków przeciwpłytkowych. Folia Cardiol Excerpta 2009; 4: 10-17.

2. Kośmicki M. Zastosowanie kwasu acetylosalicylowego u pacjentów z chorobą niedokrwienną serca. Kardiologia Oparta na Faktach 2011; 1: 52-66.

3. Charakterystyka Produktu Leczniczego [Internet]. Available from: https:// lekomanprod.blob.core.windows.net/product-documents/doc13201/aspirincardio-dokument.pdf

4. Grinstein J, Cannon CP. Aspirin resistance: current status and role of tailored therapy. Clin Cardiol 2012; 35: 673-681.

5. Maree AO, Curtin RJ, Dooley M, Conroy RM, Crean P, Cox D, Fitzgerald DJ. Platelet response to low-dose enteric-coated aspirin in patients with stable cardiovascular disease. J Am Coll Cardiol 2005; 46: 1258-1263.

6. Cox D, Maree AO, Dooley M, Conroy R, Byrne MF, Fitzgerald DJ. Effect of enteric coating on antiplatelet activity of low-dose aspirin in healthy volunteers. Stroke 2006; 37: 2153-2158.

7. Catella-Lawson F, Reilly MP, Kapoor SC, Cucchiara AJ, DeMarco S, Tournier B, Vyas SN, FitzGerald GA. Cyclooxygenase inhibitors and the antiplatelet effects of aspirin. N Engl J Med 2001; 345: 1809-1817.

8. Csiszar A, Stef G, Pacher P, Ungvari Z. Oxidative stress-induced isoprostane formation may contribute to aspirin resistance in platelets. Prostaglandins Leukot Essent Fatty Acids 2002; 66: 557-558.

9. Christiaens L, Macchi L, Herpin D, Coisne D, Duplantier C, Allal J. Resistance to aspirin in vitro at rest and during exercise in patients with angiographically proven coronary artery disease. Thromb Res 2002; 108: 115-119.

10. Weber AA, Przytulski B, Schanz A, Hohlfeld T, Schrör K. Towards a definition of aspirin resistance: a typological approach. Platelets 2002; 13: 37-40.

11. Cuisset T, Frere C, Quilici J, Gaborit B, Bali L, Poyet R, Faille D, Morange PE, Alessi MC, Bonnet JL. Aspirin noncompliance is the major cause of "aspirin resistance" in patients undergoing coronary stenting. Am Heart J 2009; 157: 889-893.

12. Lordkipanidzé M, Pharand C, Palisaitis DA, Diodati JG. Aspirin resistance: truth or dare. Pharmacol Ther 2006; 112: 733-743.

13. Postuła M, Kapłon-Cieślicka A, Rosiak M, Filipiak K. Nieprawidłowa odpowiedź na kwas acetylosalicylowy - definicje i zasady postępowania w świetle poznanych czynników ryzyka. Pol Heart J 2008; 66 (10 Suppl. 3): 326-331.

14. Wożakowska-Kapłon B, Filipiak K, Mamcarz A, Narkiewicz K, Tykarski A, Widecka K. Miejsce wystandaryzowanego ekstraktu z pomidorów w prewencji pierwotnej schorzeń układu sercowo-naczyniowego. Czy i kiedy stanowi alternatywę dla kwasu acetylosalicylowego? Stanowisko grupy ekspertów. Folia Cardiol 2015; 10: 100-105.

15. Antithrombotic Trialists' (ATT) Collaboration, Baigent C, Blackwell L, Collins R, Emberson J, Godwin J, Peto R, Buring J, Hennekens C, Kearney P, Meade T, Patrono C, Roncaglioni MC, Zanchetti A. Aspirin in the primary and secondary prevention of vascular disease: collaborative meta-analysis of individual participant data from randomised trials. Lancet 2009; 373: 1849-1860.

16. Berger JS, Lala A, Krantz MJ, Baker GS, Hiatt WR. Aspirin for the prevention of cardiovascular events in patients without clinical cardiovascular disease: a meta-analysis of randomized trials. Am Heart J 2011; 162: 115-24.e2.

17. Goff DC Jr, Lloyd-Jones DM, Bennett G, Coady S, D'Agostino RB, Gibbons R, Greenland P, Lackland DT, Levy D, O’Donnell CJ, Robinson JG, Schwartz JS,
Shero ST, Smith SC Jr, Sorlie P, Stone NJ, Wilson PW, Jordan HS, Nevo L, Wnek J, Anderson JL, Halperin JL, Albert NM, Bozkurt B, Brindis RG, Curtis LH, DeMets D, Hochman JS, Kovacs RJ, Ohman EM, Pressler SJ, Sellke FW, Shen WK, Smith SC Jr, Tomaselli GF; American College of Cardiology/American Heart Association Task Force on Practice Guidelines. 2013 ACC/AHA guideline on the assessment of cardiovascular risk: a report of the American College of Cardiology/American Heart Association Task Force on Practice Guidelines. Circulation 2014; 129 (25 Suppl. 2): S49-S73.

18. Pignone M, Alberts MJ, Colwell JA, Cushman M, Inzucchi SE, Mukherjee D, Rosenson RS, Williams CD, Wilson PW, Kirkman MS. Aspirin for primary prevention of cardiovascular events in people with diabetes: a position statement of the American Diabetes Association, a scientific statement of the American Heart Association, and an expert consensus document of the American College of Cardiology Foundation. Circulation 2010; 121: 26942701.

19. World Health Organization. WHO Fruit and Vegetable Promotion Initiative - report of the meeting,

20. Miazga A, Kostka-Jeziorny K, Begier-Krasińska B, Tykarski A. Wystandaryzowany ekstrakt z pomidorów (Fruitflow) - czy stanowi alternatywę dla kwasu acetylosalicylowego w profilaktyce pierwotnej chorób sercowo-naczyniowych u pacjentów z nadciśnieniem tętniczym? Arter Hypertens 2014; 18: 37-42.

21. O'Kennedy N, Crosbie L, van Lieshout M, Broom JI, Webb DJ, Duttaroy AK. Effects of antiplatelet components of tomato extract on platelet function in vitro and ex vivo: a time-course cannulation study in healthy humans. Am J Clin Nutr 2006; 84: 570-579.

22. Fuentes E, Forero-Doria O, Carrasco G, Maricán A, Santos LS, Alarcón M, Palomo I. Effect of tomato industrial processing on phenolic profile and antiplatelet activity. Molecules 2013; 18: 11526-11536.

23. European Food Safety Authority (EFSA). Water-soluble tomato concentrate (WSTC I and II) and platelet aggregation. EFSA J 2009; 7.

24. O'Kennedy N, Raederstorff D, Duttaroy AK. Fruitflow ${ }^{\circledR}$ : the first European Food Safety Authority-approved natural cardio-protective functional ingredient. Eur J Nutr 2017; 56: 461-482.

25. Palomo I, Fuentes E, Padró T, Badimon L. Platelets and atherogenesis: platelet anti-aggregation activity and endothelial protection from tomatoes (Solanum lycopersicum L.). Exp Ther Med 2012; 3: 577-584.

26. Fuentes E, Castro R, Astudillo L, Carrasco G, Alarcón M, Gutiérrez M, Palomo I. Bioassay-guided isolation and HPLC determination of bioactive compound that relate to the antiplatelet activity (adhesion, secretion, and aggregation) from solanum lycopersicum. Evid Based Complement Altern Med ECAM 2012; 2012: 147031.

27. Schwager J, Richard N, Mussler B, Raederstorff D. Tomato aqueous extract modulates the inflammatory profile of immune cells and endothelial cells. Molecules 2016; 21: 168.

28. Navarrete S, Alarcón M, Palomo I. Aqueous extract of tomato (Solanum lycopersicum L.) and ferulic acid reduce the expression of TNF-alpha and IL-1alpha in LPS-activated macrophages. Molecules 2015; 20: 15319-15329.

29. Biswas D, Uddin MM, Dizdarevic LL, Jřrgensen A, Duttaroy AK. Inhibition of angiotensin-converting enzyme by aqueous extract of tomato. Eur J Nutr 2014; 53: 1699-1706. 